In its first year, The Commonwealth of Learning focused on a limited number of objectives. These included work on the cooperative use of teaching materials in accounting, business education, and management; the sciences; agriculture/rural development; health; education and training of teachers; womens' studies; the establishment of Commonwealth-wide information services, and staff training in cooperation with partner institutions. While the start was modest, the long-term aim is bold: "to look forward to the day when any learner, anywhere in the Commonwealth, shall be able to study any distance-teaching programme available from any bona fide college or university in the Commonwealth'.

\section{Where Will it Work?}

Through the generosity of the Canadian and British Columbian Governments, the headquarters is in Vancouver, Canada. However, much of the work of The Commonwealth of Learning will be decentralized. It will work closely with colleges and universities in all parts of the Commonwealth, and will arrange for much of its work on the development of materials and the provision of consulting services to be carried out under contract. For example, its principal information services will emanate from the International Centre for Distance Learning operated by the British Open University.

Wherever possible, The Commonwealth of Learning will foster regional programmes and consortia. Precedents for arrangements of this type already exist in the Commonwealth at the University of the South Pacific and at the University of the West Indies. In time, regional arrangements may be established in other parts of the Commonwealth, such as Nigeria, India, and the southern African countries.

\section{Who Runs It and Pays for It?}

The Commonwealth of Learning is governed by a Board that is representative of all parts of the Commonwealth. It consists of a Chairman plus nine members representing Governments, five individual members, and two ex officio members who are the Commonwealth Secretary-General and the President of The Commonwealth of Learning. Five of the Board members represent Governments that have pledged the largest contributions to its funds. At present these are Britain, Brunei Darussalam, Canada, India, and Nigeria. Four other Government Board members represent geographical areas. These are Australia, Barbados, Malta, and Zimbabwe. The first Chairman is Lord Briggs of Lewes (better known as Professor Asa Briggs) and the President is Dr James A. Maraj.

The Commonwealth of Learning has been launched with pledges of funds from Commonwealth Governments amounting to approximately 15 million (pounds) for its first five years. The Organization is expected to raise funds from governmental and non-governmental agencies and from the private sector in order to finance individual projects and programmes. Specific enquiries and useful comments may be addressed to the undersigned.*

\section{James A. Maraj, President \\ The Commonwealth of Learning 300-800 Hornby Street \\ Vancouver \\ British Columbia V6Z 2C5 Canada.}

\footnotetext{
* To whom we recommend environmentalists and conservationists to write strongly to emphasize the splendid opportunities which The Commonwealth of Learning offers for extending
} knowledge and appreciation of their two vital themes. - Ed.

\title{
For Geologists: A Code of Conduct for Rock-coring
}

Thoughtless behaviour by some parties in recent years has brought geological field-work close to prohibition in parts of Britain and elsewhere. Acceptance of a selfimposed Code of Conduct has done much to defuse that situation, and happily we have today a reasonable working relationship with both industry and landowners, to our very great benefit. However, such agreements must inevitably hang in a state of delicate balance that is liable to be upset by a single act of thoughtlessness by even a small minority of offenders.

An example of the response that such want of thought can provoke is to be seen in the reaction of country-goersgeologists among them - to the widespread practice of scarring rock outcrops by the extraction of small-diameter cores for geological research. When such coring first began as a technique for sampling, it was normally discrete in location and limited in scale. Now, however, it seems to be common practice to take cores in clusters, for instance from the contact zones of igneous rocks or from sedimentary boundaries, or else from the cores of folds. Sometimes the attack appears to be systematically three-dimensional. Fig. 1 shows an example used in the circulated Code of Conduct.

Needless to say, coring on this scale has resulted in some very unsightly damage, and has ruined the appearance and photographic value of several well-known localities, such as the Zechstein reef contacts in Durham (Fig. 2), or the Ludlow slump structures. Every igneous dyke, no matter how thin, seems to draw the attention of covers, and various stratigraphically important sections. e.g. the Middle

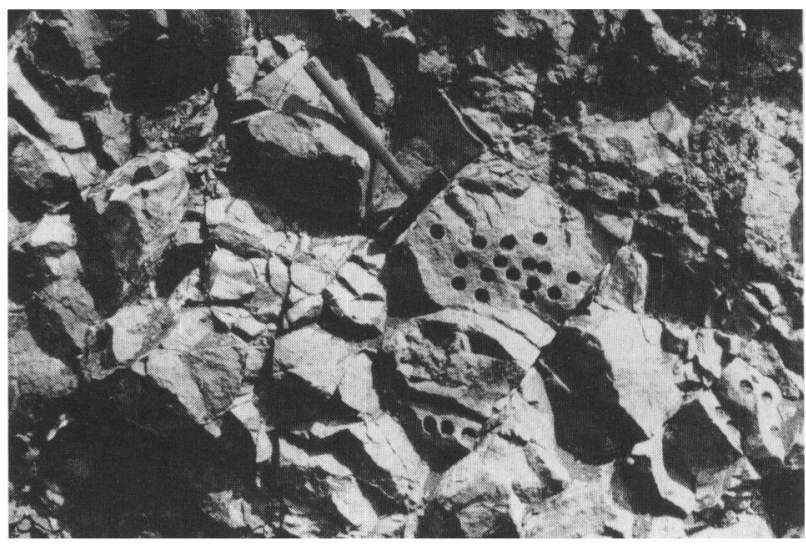

FIG. 1. Photograph of Cyprus pillow lava used in the circulated Code of Conduct. Geologist's hammer gives scale. Photo: Prof. J. Knill.

Jurassic in the Burton Bradstock road-cut, where previously geologists had accepted a 'no hammering' restriction, have lately suffered extensive damage by coring.

Unlike hammering, which might be the work of just anyone with only the remotest connection with organized geology, coring can only be the result of premeditated acts on the part of specialist research workers backed by geological centres of study, who should know better how to behave in the field. 


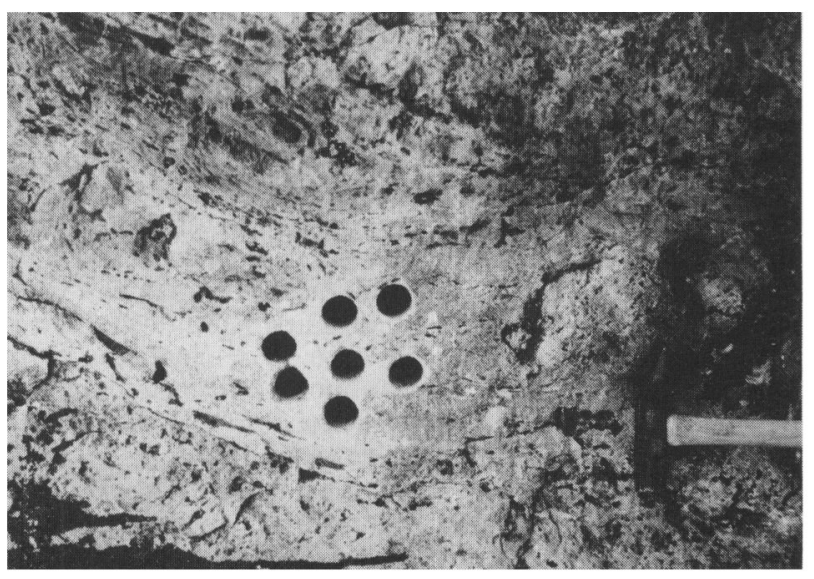

FIG. 2. Zechstein reef facies, Tunstall Hill, Sunderland, County Durham. Approx. half of handle of Geologist's hammer (below on right) gives scale. Photo: Dr Denys Smith.

For this reason it seems preferable not to conduct any individual witch-hunt but rather to ask everybody to support a self-regulatory Code of Conduct embodying the following principles:

1. Take cores from the least-exposed faces and avoid those which are most obviously visible on entering a quarry or approaching a natural exposure.
2. Take only the minimum number of cores necessary, and avoid closely-spaced patterns, which will attract undue attention.

3. As best you can, try to plug the holes with quarry debris of similar type and colour to the surrounding rock. Wherever possible, re-fill the holes with plugs of a slightly smaller diameter drilled from fallen blocks of the same material.

4. Have respect for the feelings of other geologists who may well, against their own natural instincts but out of regard for others, have already consented to a 'no hammering' limitation at the same locality.

It is clear from the literature of geology that careless rock-coring is a world-wide problem and one that is by no means confined to the British Isles. If we were to achieve wide-ranging support for such voluntary self-restraints. we could justly feel that we had scored a very significant success.

ERIC ROBINSON
G.A. Librarian \& Press Officer
Department of Geology
University College London
Gower Street
London WC1E $6 B T$
England, UK.

\section{Success Against Shifting Sands in Uzbekistan}

The article in Environmental Awareness (vol. 12, pp. 73-4, 1989), entitled 'Success Against Shifting Sands', by Monique Mainguet, describing the work of Sekkou Zouha in controlling moving sand-dunes in Morocco, reminded me of a comparable situation observed in 'Middle Asia' in 1975.

My observations were made on the excursion after the XII International Botanical Congress, Leningrad, 1975, to Uzbekistan, formerly Russian Turkestan. One of the field trips on this excursion was from the fabled city of Bukhara to beyond Shafrikan on the southeastern edge of the remarkable Kyzyl-Kum Desert, lying to the south-east of the Aral Sea. Here, moving dunes tend to encroach on the inhabited area of which Bukhara is the centre.

A short visit to the actual desert of huge, active, crescentshaped or 'barkan' dunes left a lasting impression, both of the majesty of these vast sands, and of the ingenious ways in which plants have adapted to life in this difficult 'habitat'. Most conspicuous were the umbelliferous Ferula asafoetida, monocarpic, with a large crown of horizontal fruiting branches at the top of a well-rooted, erect, thick, pithy, trunk-like stem, at the time of our visit dormant and leafless; Haloxylon aphyllum, a shrub with no leaves but thick green photosynthetic stems: Aristida karelinii, a large tightly-clumped grass with an extensive spreading root-system of horizontal roots radiating under the sand-surface to several metres in all directions; and Alhagi canescens, one of the 'camel-thorns', a rigid microphyllous to leafless shrub, and constituting one of the dominants in this sparse vegetation.

Out from Shafrikan was a wooded hill, topped by ruins of the Vardanzy Castle, a fortification of the ancient Tsars of Middle Asia, and more ancient even than Bukhara. From the base of this hill we walked through a forest of Haloxylon aphyllum, here reaching small-tree size, of the Chenopodiaceae-a family familiar to most of the party as herbaceous garden weeds. In the undergrowth were shrubs of Alhagi sp., Tamarix sp., Lycium muthenicum, a species of Zygophyllum, the Common Reed, Phragmites australis, and the herbaceous 'vine' Cynanchum sibiricum.

The flat top of the hill bore a different type of vegetation-semi-open, among stonework ruins. Here we were given a short talk by a botanist from the Bukhara branch of the Tashkent Botanical Institute. She explained that the area had been an important trade centre in the 19th Century, that it had been inhabited until the 1930s, and that the area we had been walking through had then been a town. The dunes had moved in from the desert and buried the town, so that the area we had been walking over was actually the site of the buried town. The forest is entirely artificial. In 1936 the Botanical Institute was instructed by the Government to undertake a project to stabilize the dunes - to stop their encroachment on the fertile agricultural Serafshan Valley.

This thoroughly natural-appearing chenopodiaceous forest is the result of their efforts, completely successful in 30 years, in stopping the advance of the dunes.

We were informed that we were the first foreigners to visit and see this achievement, which our Russian hosts were pleased to show us.

F. Raymond FosberG, Botanist Emeritus National Museum of Natural History

Smithsonian Institution

Washington

DC 20560, USA. 